DOI: https://doi.org/10.12797/Politeja.15.2018.54.06

\title{
Beata KOSOWSKA-GĄSTOŁ
}

Uniwersytet Jagielloński

beata.kosowska-gastol@uj.edu.pl

\section{WPEYW TRAKTATU LIZBOŃSKIEGO NA EUROPEJSKIE PARTIE POLITYCZNE}

\section{ABSTRACT Impact of the Lisbon Treaty on European political parties}

The subject of the article is to analyze the relevant provisions of the Lisbon Treaty in order to show the changes they have introduced for Europarties. The main thesis of the article is that even if the direct influence of the said Treaty on Europarties was negligible, its indirect impact could be significantly greater. The article has been divided into three parts. The first recalled the genesis of the Europarties and outlined the legal framework for their activities until the entry into force of the Treaty of Lisbon. In the second one - the provisions of the Treaty directly devoted to the Europarties were analyzed. The third part depicted the areas in which - by adopting a specific interpretation of the Treaty provisions - the Europarties may try to exert an indirect influence on the EU decision-making process, especially a new way of selecting the President of the European Commission.

Keywords: Europarties, political parties at the European level, leading candidates, Spitzenkandidaten

Słowa kluczowe: europartie, partie polityczne na poziomie europejskim, wiodący kandydaci, Spitzenkandidaten 
U

powszechniające się traktowanie układu instytucjonalnego Unii Europejskiej jako systemu politycznego nie idzie w parze z postrzeganiem europartii jako partii sensu stricto. Michalis Peglis wspomina w tym kontekście o swego rodzaju instytucjonalnej asymetrii ${ }^{1}$. W porównaniu $\mathrm{z}$ funkcjami pełnionymi przez partie $\mathrm{w}$ poszczególnych państwach rola europartii w systemie UE wydaje się nader skromna ${ }^{2}$. Wybory do Parlamentu Europejskiego zdominowane są przez partie krajowe, a prace w tym organie strukturyzowane przez grupy polityczne. Nie oznacza to jednak, że pozaparlamentarne europartie są pozbawione znaczenia. Rozwijają one swoje struktury i stopniowo dążą do wykonywania funkcji tradycyjnie przypisywanych partiom ${ }^{3}$, ponadto są jedynymi aktorami tworzącymi powiązania między politykami wchodzącymi w skład Komisji, Rady i Rady Europejskiej, czemu służą m.in. szczyty partyjne ${ }^{4}$. Steven van Hecke trafnie zauważył, że nawet jeśli wpływ wywierany przez europartie nie jest duży, to maty wptyw na bardzo ważny proces może generowaćpoważne konsekwencjes. Dlatego pozostają one ważnym przedmiotem dociekań naukowych.

Pomimo ciągłego istnienia wspomnianej asymetrii instytucjonalnej, nie można nie doceniać faktu, że europartie stopniowo umacniają swoją pozycję. Służą temu zmiany wprowadzane do prawa traktatowego UE, a także akty prawne Rady i PE. Przedmiotem niniejszego artykułu jest analiza odnośnych przepisów traktatu lizbońskiego w celu ukazania zmian, jakie za jego sprawą mogą być udziałem europartii ${ }^{6}$. Główną tezę można sprowadzić do stwierdzenia, że nawet jeśli bezpośredni wpływ traktatu z Lizbony na europartie nie był znaczący, to jego pośrednie oddziaływanie może być znacznie większe. Wiąże się to z określonymi interpretacjami przepisów traktatu, które - nawet jeśli dotyczą innych instytucji - mogą wywierać wpływ także na pozycję i znaczenie

1 M. Peglis, How Can European Political Parties Maximise Their Success in the 2019 Elections?, „European View" 2015, vol. 14, nr 1, s. 21-30, [online] https://doi.org/10.1007/s12290-015-0354-6, 30 III 2018.

2 H.H. von Arnim, M. Schurig, The European Party Financing Regulation, Münster 2004, s. 28-29.

3 B. Kosowska-Gąstol, Europejskie partie polityczne jako organizacje wielopoziomowe. Rozwój, struktury, funkcje, Kraków 2014, s. 218-261.

4 Karl M. Johansson utrzymywanie powiązań pomiędzy różnymi płaszczyznami wielopoziomowego systemu politycznego UE uznał wręcz za raison d'ètre europejskich partii. K.M. Johansson, Towards a Theory of Federations of Political Parties in Multilevel Europe: at the Nexus of International Relations and Comparative Politics, [w:] The Europarties. Organisation and Influence, red. P. Delwit, E. Külahci, C. Van de Walle, Brussels 2004, s. 18-19.

5 S. van Hecke, Do Transnational Party Federations Matter? (... and Why Should We Care?), „Journal of Contemporary European Research" 2010, vol. 6, nr 2, s. 407.

6 Warto w tym miejscu zwrócić uwagę, że artykuł poświęcony został pozaparlamentarnym europartiom, nie zaś powiązanym z nimi grupom politycznym w PE. Te ostatnie przywoływane będą niejako na marginesie i tylko w takim zakresie, jaki uznano za niezbędny do zrozumienia ich relacji z europartiami. Należy też nadmienić, że o ile w literaturze przedmiotu przyjęło się określanie omawianych tu podmiotów mianem europartii, o tyle w prawie traktatowym i w pierwszych dwóch rozporządzeniach poświęconych tym podmiotom (z 2003 i 2007 r.) konsekwentnie stosowane jest określenie partie polityczne na poziomie europejskim, a w rozporządzeniu z 2014 r. - europejskie partie polityczne. W niniejszym artykule powyższe nazwy będą stosowane zamiennie. 
europartii. W artykule zastosowano podejście neoinstytucjonalne w postaci instytucjonalizmu racjonalnego wyboru, który pozwala ukazać, jak aktorzy polityczni dostosowują się do zmieniających się ram prawnych i otoczenia instytucjonalnego (w tym wypadku: europartie do traktatu z Lizbony).

Artykuł został podzielony na trzy części. W pierwszej przypomniano genezę europartii oraz nakreślono ramy prawne ich działalności do wejścia w życie traktatu lizbońskiego. W drugiej przeanalizowano przepisy traktatu bezpośrednio poświęcone europartiom. W trzeciej zarysowano obszary, w których europartie - przyjmując określoną interpretację przepisów traktatowych - mogą próbować wywierać pośredni wpływ na proces decyzyjny UE. Dotyczy to zwłaszcza nowego sposobu wyłaniania przewodniczącego Komisji Europejskiej, który wzbudza duże nadzieje na dalszy rozwój europartii, a zarazem wywołuje najwięcej kontrowersji.

\section{UMOCOWANIE PARTII POLITYCZNYCH W PRAWIE UE}

W przypadku tworzenia krajowych partii rzeczywistość polityczna na ogół wyprzedzała stan prawny - przyjmowane przepisy sankcjonowały od dawna istniejące ugrupowania. Na płaszczyźnie europejskiej sytuacja wyglądała inaczej - prawo regulowało funkcjonowanie podmiotów, które nie istniały w rzeczywistości lub istniały jedynie w zalążkowej postaci. Przepisy prawne miały więc być swego rodzaju instytucją sprawczą, stymulującą powstanie i rozwój europartii ${ }^{7}$. Grupy polityczne zostały wprawdzie utworzone w Zgromadzeniu Europejskiej Wspólnoty Węgla i Stali zaraz po jej ukonstytuowaniu się w $1952 \mathrm{r}{ }^{8}$, niemniej jednak miały one wyłącznie wewnątrzparlamentarny charakter i nie były w żaden sposób powiązane z areną wyborczą, a ich członkowie byli powoływani przez parlamenty państw członkowskich.

Funkcjonowanie wspomnianych grup przez ponad 20 lat nie doprowadziło do utworzenia pozaparlamentarnych organizacji, które mogłyby stanowić ich zaplecze i dostarczać potrzebnego wsparcia. Dopiero zapowiedź przeprowadzenia bezpośrednich wyborów do PE na spotkaniu głów państw lub szefów rządów państw członkowskich Wspólnot Europejskich (tzw. spotkanie na szczycie) w Paryżu w 1974 r. skłoniła krajowe partie do nawiązywania współpracy także poza PE w celu lepszego przygotowania się do eurowyborów ${ }^{9}$. Decyzja ta była bezpośrednią przyczyną powstania

Argumentacja dotycząca tego stwierdzenia została rozwinięta w innym opracowaniu, dlatego tutaj zostanie pominięta. Zob. B. Kosowska-Gąstoł, „Partie polityczne na poziomie europejskim” - stan obecny i perspektywy rozwoju, [w:] Nowe strategie na nowy wiek. Granice i możliwości integracji regionalnych i globalnych, red. M. Chorośnicki [i in.], Kraków 2013, s. 137-149.

8 Zgromadzenie przyjęło rezolucję dotyczącą tworzenia grup politycznych 16 VI 1953 r., niemniej jednak pierwsze grupy ukształtowały się jeszcze w 1952 r., mimo braku przepisów prawnych w tym zakresie.

9 Final communique of the Paris Summit (9 and 10 December 1974), „Bulletin of the European Communities”, nr 12, Luxembourg, XII 1974, [online] http://www.cvce.eu/obj/final_communique_of_the_ paris_summit_9_and_10_december_1974-en-2acd8532-b271-49ed-bf63-bd8131180d6 b. 30 III 2018. 
transnarodowych federacji partii, stanowiących zalążki europartii. Po fazie optymizmu odnośnie do możliwości szybkiego powstania prawdziwie europejskich partii nastąpiła jednak stagnacja, którą przerwało dopiero wejście w życie kolejnych aktów prawnych Jednolitego Aktu Europejskiego ${ }^{10}$ oraz traktatu z Maastricht ${ }^{11}$. Okres ten został uznany za początek fazy renesansu europartii ${ }^{12}$.

Dla rozwoju współpracy partyjnej duże znaczenie miał zwłaszcza traktat z Maastricht, w którym wprowadzono do prawa pierwotnego UE tzw. artykuł partyjny (art. 138a TWE), w którym stwierdzono, że partie polityczne na poziomie europejskim sq ważnym czynnikiem integracji w ramach Unii. Przyczyniaja się one do ksztattowania świadomości europejskiej i wyrażania woli politycznej obywateli Unii ${ }^{13}$. Z uwagi na fakt, że nie było w tym czasie podmiotów, które można było uznać za partie polityczne na poziomie europejskim $\mathrm{i}$ które spełniałyby zadekretowane w traktacie funkcje, wspomnianemu artykułowi należy przypisać raczej rolę programową. Oczekiwano, że będzie on samospełniającą się przepowiednią, co w dużej mierze się sprawdziło. Nawet jeśli artykuł był ogólną deklaracją polityczną, przyniósł nowe nadzieje i przyczynił się do ożywienia partyjnej współpracy w ramach transnarodowych federacji. Niektóre z nich zmieniły nazwy, dodając do dotychczasowych określenie partia, dokonały też odpowiednich przekształceń w swoich statutach. Spodziewano się, że w ślad za tzw. konstytucjonalizacją europartii ${ }^{14}$ przyjęte zostaną szczegółowe przepisy niższego rzędu. Tak się jednak nie stało. Sytuacja nie uległa zmianie także po przyjęciu traktatu z Amsterdamu, który w zakresie europartii przyniósł jedynie zmiany formalne polegające na nadaniu nowej numeracji: dawny art. 138a TWE stanowił odtąd art. 191 TWE $^{15}$.

Zmiany o charakterze merytorycznym wprowadził dopiero traktat z Nicei. Do artykutu partyjnego dodano drugi akapit, w którym wezwano Radę i PE do określenia w procedurze współdecydowania statusu i zasad finansowania partii politycznych na poziomie europejskim ${ }^{16}$. Rozporządzenie w tej sprawie zostało wydane 4 listopada $2003 \mathrm{r}$. Określono w nim m.in., jakie warunki musi spełniać organizacja, aby mogła uzyskać status europartii oraz finansowanie z budżetu $\mathrm{UE}^{17}$. Rozporządzenie to doczekało się

10 Jednolity Akt Europejski, Dz.U. UE L 169, 29 VI 1987.

11 Traktat o Unii Europejskiej (traktat z Maastricht), Dz.U. UE C 191, 29 VII 1992.

12 Fazy optymizmu, stagnacji oraz renesansu zostały wyróżnione przez Simona Hixa. Zob. S. Hix, The Transnational Party Federations, [w:] Political Parties and the European Union, red. J. Gaffney, London-New York 1996, s. 312-321.

13 Traktat o Unii Europejskiej...

14 Pojęcie konstytucjonalizacja rozumiane jest zazwyczaj jako odzwierciedlenie funkcjonowania partii w porządku konstytucyjnym danego państwa. W przypadku UE za normy konstytucyjne uznaje się te zawarte w prawie traktatowym. M. Jastrzębski, Status prawny partii politycznych na poziomie europejskim, [w:] T. Godlewski [i in.], Wspótczesne partie polityczne. Wybrane problemy, Toruń 2009, s. 115.

15 Traktat z Amsterdamu, Dz.U. UE C 340, 10 XI 1997.

16 Traktat $z$ Nicei, Dz.U. UE C 80, 10 III 2001.

17 Rozporządzenie (WE) nr 2004/2003 Parlamentu Europejskiego i Rady z dnia 4 listopada 2003 r. w sprawie przepisów regulujacych partie polityczne na poziomie europejskim oraz zasad dotyczacych ich finansowania, Dz.U. UE L 297, 15 XI 2003. 
nowelizacji dokonanej 18 grudnia 2007 r., której celem było zwiększenie skuteczności wspólnotowych przepisów regulujących działalność i finansowanie europartii ${ }^{18}$. Oprócz tego nowelizacja umożliwiła zakładanie przy europartiach tzw. fundacji politycznych na poziomie europejskim, będących swego rodzaju partyjnymi think tankami.

\section{ZMIANY W STATUSIE PRAWNYM EUROPARTII WPROWADZONE PRZEPISAMI TRAKTATU Z LIZBONY}

W traktacie lizbońskim w zasadzie powtórzono wcześniejsze przepisy dotyczące europartii, umieszczając je jednak w innych miejscach. W literaturze przedmiotu zwrócono uwagę, że wprowadzone zmiany mają charakter symboliczny, porządkowy i formalny ${ }^{19}$. Niemniej jednak, zgodnie z ustaleniami doktryny prawa konstytucyjnego, systematyka aktu prawnego może mieć duże znaczenie interpretacyjne, dlatego warto bliżej przyjrzeć się temu, w której części traktatu umieszczono przepisy poświęcone europartiom oraz jaki to może mieć wpływ na ich pozycję.

Art. 191 TWE, regulujący status europartii z traktacie nicejskim, w traktacie lizbońskim został podzielony na dwie części; jedna stała się częścią Traktatu o Unii Europejskiej (art. 10 ust. 4 TUE), druga - Traktatu o funkcjonowaniu Unii Europejskiej (art. 224 TFUE) ${ }^{20}$. Ponadto przepisy dotyczące europartii zostały częściowo powtórzone w Karcie Praw Podstawowych UE (art. 12 ust. 2 KPP UE) ${ }^{21}$. Tab. 1 obrazuje zmiany w tym zakresie.

Z art. 191 TWE usunięto pierwsze zdanie zawierające deklarację, iż europartie są ważnym czynnikiem integracji $w$ ramach Unii, co należy uznać za zasadne, albowiem żadna konstytucja nie zawiera stwierdzenia o ważności partii funkcjonujących w ramach państwa (uznaje się to za oczywiste). Konstytucje skupiają się raczej na nakreśleniu funkcji partii. Te zostały zawarte w kolejnym zdaniu wspomnianego artykułu, które umieszczono teraz w art. 10 TUE jako ust. 4. Artykuł jest w całości poświęcony demokracji przedstawicielskiej, którą uznano za podstawę funkcjonowania UE (ust. 1). Obywatele są reprezentowani na poziomie Unii w Parlamencie Europejskim (ust. 2), zaś państwa członkowskie są reprezentowane w Radzie Europejskiej przez szefów państw lub rządów oraz w Radzie przez rządy krajowe, które odpowiadają przed swoimi parlamentami lub obywatelami (ust. 2). Każdy obywatel ma prawo uczestniczyć

18 Rozporzadzenie (WE) nr 1524/2007 Parlamentu Europejskiego i Rady z dnia 18 grudnia 2007 r. zmieniające rozporządzenie (WE) nr 2004/2003 w sprawie przepisów regulujących partie polityczne na poziomie europejskim oraz zasad dotyczacych ich finansowania, Dz.U. UE L 343, 27 XII 2007.

19 A. Gorgol, Prawne aspekty publicznego finansowania partii politycznych $w$ Polsce i na poziomie europejskim, Lublin 2011, s. 79.

20 Traktat lizboński, Dz.U. UE C 306, 17 XII 2007.

21 Podstawy prawne Unii Europejskiej. Traktat z Lizbony, Traktat o Unii Europejskiej, Traktat o funkcjonowaniu Unii Europejskiej wraz z protokotami i deklaracjami, Karta Praw Podstawowych. Teksty skonsolidowane traktatów uwzględniające korekty językowe, wprow., wybór i oprac. J. Barcz, Warszawa 2010, s. $63,203,456$. 
w życiu demokratycznym Unii, a decyzje powinny być podejmowane w sposób otwarty, jak najbliżej obywateli (ust. 3). Powtórzenie w tym kontekście sformułowania: Partie polityczne na poziomie europejskim przyczyniaja się do ksztattowania europejskiej świadomości politycznej i wyrażania woli obywateli Unii nabiera nowego znacze$n a^{22}$. Europartie zostają uznane za ważne w demokracji przedstawicielskiej instytucje pośredniczące pomiędzy obywatelami oraz organami władzy. Zdaniem Marcina Jastrzębskiego jednoznaczne powiązanie ich z zasadą demokracji sprawia, że nabierają zdecydowanie większego znaczenia ${ }^{23}$.

Tab. 1. Zestawienie przepisów poświęconych europartiom w traktatach z Nicei i Lizbony

Traktat z Nicei
art. 191 TWE
Partie polityczne na poziomie europejskim
są ważnym czynnikiem integracji w ra-
mach Unii. Przyczyniaja się one do ksztal-
towania świadomości europejskiej i wy-
rażania woli politycznej obywateli Unii.
Rada, stanowiac zgodnie z procedura okre-
ślona wartykule 251, określa status partii po-
litycznych na poziomie europejskim, w szcze-
gólności zasady dotyczące ich finansowania.

\section{Traktat z Lizbony}

art. 10 ust. 4 TUE

Partie polityczne na poziomie europejskim przyczyniaja się do kształtowania europejskiej świadomości politycznej i wyrażania woli obywateli Unii.

art. 224 TFUE

Parlament Europejski i Rada, stanowiac $w$ drodze rozporzadzeń zgodnie ze zwykta procedura ustawodawcza, określaja status partii politycznych na poziomie europejskim, o których mowa $w$ artykule 10 ustęp 4 Traktatu o Unii Europejskiej, w szczególności zasady dotyczące ich finansowania.

\section{art. 12 ust. 2 KPP UE}

Partie polityczne na poziomie Unii przyczyniaja sie do wyrażania woli politycznej jej obywateli.

Źródło: opracowanie własne.

Z kolei drugi akapit dawnego art. 191 TWE, wzywający organy unijne do wydania odpowiedniego aktu prawnego regulującego status oraz zasady finansowania europartii, umieszczony został w TFUE jako art. 224. Wspomniane przepisy zostały uszczegółowione i obecnie wynika z nich jasno, że akt regulujący kwestie związane z europartiami ma mieć charakter rozporządzenia PE i Rady oraz powinien być przyjęty zgodnie z przewidzianą w traktacie lizbońskim zwykłą procedurą ustawodawczą. Po wejściu z życie traktatu wcześniejsze rozporządzenie o europartiach z 2003 r., znowelizowane w 2007 r., zostało zastąpione nowym aktem prawnym - rozporządzeniem nr 1141/2014 PE i Rady z 22 października $2014 \mathrm{r}^{24}$, które dostosowuje wcześniejsze przepisy do nowego traktatu, uwzględnia też doświadczenia związane ze stosowaniem dotychczasowego rozporządzenia.

22 W traktacie z Lizbony przesunięte zostało określenie polityczna, które wcześniej dotyczyło woli obywateli, obecnie - świadomości europejskiej.

24 Rozporządzenie (EU, Euratom) Parlamentu Europejskiego i Rady nr 1141/2014 z dnia 22 października $2014 \mathrm{r}$. w sprawie statusu i finansowania europejskich partii politycznych i europejskich fundacji politycznych, Dz.U. UE L 317, 4 XI 2014. 
Przepisy poświęcone europartiom zostały umieszczone także w Karcie Praw Podstawowych EU, która stała się odtąd częścią prawa pierwotnego. Partiom poświęcono ust. $2 \mathrm{w}$ art. 12, uzupełnia on ust. 1 wspomnianego artykułu regulujący zgromadzanie i stowarzyszanie się m.in. w celach politycznych. Powtórzono w nim stwierdzenie o europartiach jako podmiotach, które przyczyniają się do wyrażania woli politycznej obywateli. Umieszczenie przepisów o europartiach w tym dokumencie czyni zrzeszanie się w nich jednym z praw podstawowych przysługujących obywatelom UE.

Z powyższych rozważań jednoznacznie wynika, że przepisy poświęcone europartiom nie uległy w traktacie lizbońskim poważnym zmianom, jego bezpośredni wpływ na omawiane tu organizacje był więc nieznaczny. Niemniej jednak zmiana przepisów poświęconych innym instytucjom i organom unijnym stwarza nowe możliwości, które mogą być wykorzystywane również przez europartie poszukujące przez cały czas sposobów zwiększania swojego wpływu na proces decyzyjny w UE.

\section{MOŻLIWOŚCI POŚREDNIEGO ODDZIAŁYWANIA TRAKTATU LIZBOŃSKIEGO NA EUROPARTIE ZE SZCZEGÓLNYM UWZGLECDNIENIEM NOWEGO SPOSOBU POWOŁYWANIA PRZEWODNICZĄCEGO KOMISJI EUROPEJSKIEJ}

W związku z przyjęciem traktatu lizbońskiego wskazywano kilka obszarów, w których przed europartiami otworzyły się nowe możliwości działania. Wszystkie związane były z potrzebą koordynowania określonych działań, do czego europartie - będące w swej istocie sieciami powiązań - wydają się szczególnie predystynowane. Warto wspomnieć zwłaszcza o europejskiej inicjatywie obywatelskiej, nowej formule subsydiarności oraz zmienionym sposobie wyłaniania przewodniczącego Komisji Europejskiej $^{25}$. Nawet jeśli traktat nie łączy żadnej ze wspomnianych instytucji bezpośrednio z europartiami, to mogą one służyć nawiązywaniu kontaktów pomiędzy obywatelami, partiami i parlamentami krajowymi oraz organizowaniu poparcia dla określonych inicjatyw czy sprzeciwu wobec projektów aktów ustawodawczych pochodzących od organów unijnych.

Zgodnie z przepisami rozporządzenia nr 1141/2014 PE i Rady o europartiach każda $\mathrm{z}$ nich stanowi sojusz polityczny reprezentowany w co najmniej jednej czwartej państw członkowskich (przy obecnym stanie UE: siedem) ${ }^{26}$. W rzeczywistości największe europartie (Europejska Partia Ludowa - EPP, Partia Europejskich Socjalistów - PES,

\footnotetext{
B. Kosowska-Gąstol, „Partie polityczne na poziomie europejskim”..., s. 145-147.

Zgodnie z art. 3 ust. 1 pkt b wspomnianego Rozporzadzenia (EU, Euratom) Parlamentu Europejskiego $i$ Rady... europejska partia polityczna to sojusz polityczny, który sam jako taki lub jego cztonkowie sa reprezentowani w co najmniej jednej czwartej państw cztonkowskich lub przez cztonków Parlamentu Europejskiego, parlamentów narodowych, parlamentów regionalnych lub zgromadzeń regionalnych, lub sam jako taki lub jego partie cztonkowskie otrzymali, w co najmniej jednej czwartej państw cztonkowskich, co najmniej trzy procent gtosów oddanych w każdym $z$ tych państw cztonkowskich podczas ostatnich wyborów do Parlamentu Europejskiego.
} 
Porozumienie Liberałów i Demokratów na rzecz Europy - ALDE, Europejska Partia Zielonych - EGP) są reprezentowane we wszystkich lub prawie wszystkich państwach członkowskich UE, zaś europartie średniej wielkości (Partia Europejskiej Lewicy PEL, Wolny Sojusz Europejski - EFA) - w kilkunastu ${ }^{27}$. Samo odwołanie się do własnych struktur stwarza europartiom możliwość zmobilizowania obywateli, parlamentarzystów czy partii krajowych do podjęcia określonych działań związanych z inicjatywą obywatelską, zasadą subsydiarności czy wyłanianiem kandydatów na przewodniczącego KE. Ostatnia ze wspomnianych aktywności wzbudza największe zainteresowanie europartii, jest także żywo dyskutowana w organach UE i wiąże się z nią sporo kontrowersji, dlatego - z uwagi na rozmiar artykułu - dalsze rozważania zostaną skupione wyłącznie na niej.

Traktat lizboński zmienił sposób wyłaniania przewodniczącego KE, nakazując Radzie Europejskiej przeprowadzenie konsultacji oraz uwzględnienie wyborów do PE oraz wzmacniając uprawnienia Parlamentu Europejskiego, który ma teraz wybierać, a nie, jak wcześniej, zatwierdzać kandydata nominowanego przez Radę. Szczegóły zmian pokazano w tab. 2 .

Tab. 2. Zestawienie przepisów poświęconych wyborowi przewodniczącego

Komisji Europejskiej w traktatach z Nicei i Lizbony

Traktat z Nicei
Art. 214 ust. 2 TWE
Rada, zebrana w składzie szefów państw
lub rządów i stanowiąca większością kwa-
lifikowaną, nominuje osobę, którą zamie-
rza mianowá przewodniczącym Komisji;
nominacja ta jest zatwierdzana przez
Parlament Europejski.

\section{Traktat z Lizbony}

Art. 17 ust. 7 TUE

Uwzględniając wybory do Parlamentu Europejskiego i po przeprowadzeniu stosownych konsultacji, Rada Europejska, stanowiąc większością kwalifikowaną, przedstawia Parlamentowi Europejskiemu kandydata na funkcję przewodniczącego Komisji. Kandydat ten jest wybierany przez Parlament Europejski większością głosów członków wchodzących w jego skład. Jeżeli nie uzyska on większości, Rada Europejska, stanowiąc większością kwalifikowaną, przedstawia, w terminie miesiąca, nowego kandydata, który jest wybierany przez Parlament Europejski zgodnie z tą samą procedurą.

Źródło: opracowanie własne.

Przytoczone przepisy są niejednoznaczne, dlatego poddają się różnym interpretacjom. Wątpliwości budzi to, czy Rada powinna brać pod uwagę same wybory, czy też ich wyniki ${ }^{28}$, a także na czym mają polegać konsultacje. $Z$ pomocą przychodzi zapis de-

\footnotetext{
B. Kosowska-Gąstol, Europejskie partie polityczne..., s. 190, 317-338.
}

28 Według Martina Westlake’a określenie uwzględniając wybory może oznaczać tylko potrzebę zachowania równowagi politycznej, jeśli chodzi o nominacje na przewodniczących Komisji, Rady Europejskiej czy też Wysokiego Przedstawiciela ds. Zagranicznych i Bezpieczeństwa, natomiast określenie uwzględniając wynik wyborów jest węższe, a przez to może wskazywać, że chodzi o nominację kandydata z tej europartii, która zdobyła najwięcej mandatów w PE. Podaję za: W. Gagatek, Mechanizm wyłaniania kandydatów na przewodniczącego Komisji Europejskiej przez partie polityczne na poziomie europejskim: geneza, założenia, konsekwencje polityczne i instytucjonalne (w druku). 
klaracji 11: Konsultacje będą koncentrowaty się na kwalifikacjach kandydatów na urząd przewodniczącego Komisji, z uwzględnieniem wyborów do PE [...] $]^{29}$.

W Parlamencie Europejskim oraz w większości europartii zaczęła upowszechniać się interpretacja, zgodnie z którą wybór przewodniczącego KE powinien być uzależniony od układu sił w PE; uważa się nawet, że europartia, która wygra wybory, będzie miała prawo wskazać swojego kandydata na to stanowisko. Znalazło to odzwierciedlenie w orędziu o stanie UE z 2012 r., w którym ówczesny przewodniczący KE José Manuel Durão Barroso wezwał europartie do przedstawienia swoich wiodących kandydatów (leading candidates, Spitzenkandidaten) jeszcze przed wyborami w 2014 r., tak aby mogli oni wziąć udział w kampanii, nadając jej prawdziwie europejski wymiar. Swoich kandydatów wskazało pięć głównych partii (EPP, PES, ALDE, EGP, PEL). Spośród liczących się sił politycznych w procesie wyłaniania Spitzenkandidaten nie wzięli udziału tylko konserwatyści (Sojusz Europejskich Konserwatystów i Reformatorów - AECR), którzy nie zgadzali się z taką interpretacją traktatu. Jako pierwsi swojego kandydata przedstawili socjaliści, w ślad za nimi kolejne rodziny partyjne. Europartie zastosowały przy tym procedury zbliżone do tych wykorzystywanych podczas wyłaniania liderów partii, co można tłumaczyć krótkim okresem, jaki pozostał do wyborów ${ }^{30}$. Oryginalną procedurę przyjęła partia zielonych, która zgodnie z głoszonymi poglądami zdecydowała się wyłonić dwóch wiodących kandydatów różnych płci, ponadto zastosowano wybór w otwartych prawyborach. Pozostałe europartie powierzyły to zadanie kongresom partyjnym.

W walce o stanowisko przewodniczącego Komisji liczyli się przede wszystkim kandydaci dwóch największych partii - EPP i PES, inne postrzegały proces wyłaniania i przedstawiania Spitzenkandidaten jako szansę na zaprezentowanie swojego programu, zwiększenie rozpoznawalności i personalizację kampanii, co mogło się przyczynić do poprawy ich wyników wyborczych. Kampania informacyjna PE była prowadzona pod hasłem: Tym razem jest inaczej!; próbowano przekonać wyborców do głosowania, wskazując, że ich głos ma realne znaczenie. Od tego, kto wygra wybory, zależeć bowiem miała obsada stanowiska przewodniczącego KE, tak jak w systemach parlamentarnych od wyniku wyborów zależy obsada stanowiska premiera. Wiodący kandydaci brali aktywny udział w kampanii, odwiedzali państwa członkowskie, występowali w mediach oraz uczestniczyli w europejskich debatach o zróżnicowanym charakterze. Niektóre z nich odbywały się z udziałem kandydatów dwóch głównych partii - chadeckiej i socjalistycznej (Jean-Claude Juncker i Martin Schulz), w innych brali udział także przedstawiciele liberałów i zielonych (Guy Verhofstadt i Ska Keller lub José Bové) lub wszystkich pięciu europartii, które wyłoniły wiodących kandydatów, w tym również Aleksis Tsipras z radykalnie lewicowej PEL.

Zwycięstwo wyborcze w maju 2014 r. odniosła EPP, uzyskując 221 mandatów. Zgodnie z zapowiedziami Spitzenkandidat tej partii, Jean-Claude Juncker, był wskazywany

Podstawy prawne Unii Europejskiej..., s. 398.

30 G.-J. Put [i in.], The Choice of Spitzenkandidaten: A Comparison Analysis of the Europarties' Selection Procedures, „Politics and Governance” 2016, vol. 4, nr 1, s. 9-22, [online] https://doi.org/10.17645/ pag.v4i1.469, 30 III 2018. 
jako główny pretendent do stanowiska przewodniczącego KE. Rada Europejska nie poparła go jednak na swoim pierwszym posiedzeniu po majowych wyborach w $2014 \mathrm{r}$. Wskazywano na brak automatyzmu, który polegałby na bezdyskusyjnym akceptowaniu przez RE wiodącego kandydata partii zwycięskiej i sprowadzenia jej do roli notariusza $^{31}$. Powoływano się na wspomnianą deklarację 11, z której wynika, że konsultacje pomiędzy RE oraz PE mają dotyczyć kandydatów (w liczbie mnogiej), nie może więc być mowy o narzucaniu Radzie uzgodnionego przez partie kandydata. Stanowisko PE, a także szeroko pojęta opinia publiczna, w tym media i intelektualiści biorący udział w debacie europejskiej, nawoływały do akceptacji Junckera. W kampanii obiecywano, że tym razem będzie inaczej, gdyby więc kandydat wyłoniony z udziałem wyborców został pominięty na rzecz polityka uzgodnionego nieformalnie przez elity europejskie, wyborcy mogliby się poczuć oszukani i w kolejnych wyborach trudno byłoby przekonywać, że ich głos ma znaczenie. Tego typu argumentacja i fala krytyki sprawiły, że RE zdecydowała się większością kwalifikowaną (przy sprzeciwie premiera Wielkiej Brytanii Davida Camerona i premiera Węgier Viktora Orbána) poprzeć Junckera jako kandydata na stanowisko przewodniczącego KE. Został on ostatecznie wybrany, uzyskując w PE 422 spośród 729 oddanych głosów.

Sukces Junckera nie oznacza jednak sukcesu samej instytucji Spitzenkandidaten. Wbrew oczekiwaniom, personalizacja wyborów i powiązanie ich wyniku z powoływaniem przewodniczącego KE nie doprowadziły do zwiększenia frekwencji wyborczej. Wyniosła ona 43,09\%, utrzymała się więc na podobnym poziomie jak w 2009 r. (42,97\%). Mimo podejmowanych wysiłków rozpoznawalność wiodących kandydatów była niewielka, w wielu państwach nie było też żadnych przekazów radiowo-telewizyjnych z prowadzonych debat. Obywatele nie byli świadomi związku pomiędzy własnym głosem oraz wyborem przewodniczącego KE. Z punktu widzenia tematyki niniejszego artykułu warto jednak zauważyć, że wspomniany mechanizm można mimo wszystko uznać za sukces europartii. Pięć z nich podjęło wysiłek związany z wyłonieniem wspólnego wiodącego kandydata i w każdym przypadku zakończył się on sukcesem. Doszło więc do wzrostu znaczenia europartii poprzez fakt, że wkroczyły w nowy obszar działań, wiążący się z realizacją jednej z klasycznych funkcji partii, jaką jest wyłanianie kandydatów w wyborach oraz obsada stanowisk. Dostosowując swoje działania do przepisów traktatu z Lizbony, nadały im odpowiednią interpretację, pozwalającą na poszerzenie pola aktywności europartii i ich upodobnienie się do partii politycznych sensu stricto.

\section{ZAKOŃCZENIE}

W artykule wskazano na wpływ, jaki uwarunkowania formalne - przepisy prawne i przekształcenia instytucjonalne - wywierają na aktorów politycznych. Na przykładzie traktatu z Lizbony pokazano, że nawet jeśli zmiany poświęcone europartiom były

31 W. Gagatek, Mechanizm wyłaniania kandydatów... 
niewielkie, forsują one - dążąc do umocnienia swojej pozycji - korzystne dla siebie interpretacje i szukają możliwości wpływania na proces decyzyjny UE. Przykładem może być taka wykładnia przepisów traktatu, w której uwzględniane jest ich stanowisko w kwestii wyboru przewodniczącego KE. Europartie mają tu swoich sojuszników, do których należą niewątpliwie PE oraz KE.

W obliczu kolejnych eurowyborów w 2019 r. Parlament Europejski przyjął nawet rezolucję, w której deklaruje, że nie poprze kandydata przedstawionego przez Radę Europejską, który nie był wcześniej wiodącym kandydatem ${ }^{32}$. Rezolucja ta ma jednak symboliczne znaczenie, ponieważ w żaden sposób nie wiąże PE kolejnej kadencji. Podobną opinię wyraził obecny przewodniczący KE Juncker w orędziu o stanie UE w 2017 r.: Jeżeli chcemy wzmocnić europejska demokracje, nie możemy odwrócić demokratycznego postępu, jakim jest system gtównych Spitzenkandidaten ${ }^{33}$. Odmienne stanowisko zajmuje jednak Rada Europejska. Według jej przewodniczącego Donalda Tuska przedstawienie kandydata na stanowisko przewodniczącego KE jest autonomiczną kompetencją RE i nie można jeszcze przed wyborami zagwarantować, iż zaproponuje ona jednego z wiodących kandydatów. Jego zdaniem szef Komisji Europejskiej proponowany jest przez demokratycznie wybranych liderów państw członkowskich, a następnie wyłaniany przez demokratycznie wybrany PE, ma więc podwójną demokratyczną legitymację. Nie jest wykluczone, że RE wskaże wiodącego kandydata partii zwycięskiej, ale nie może w tym względzie być mowy o automatyzmie pozbawiającym Radę prawa decydowania ${ }^{34}$. Zgodnie z wyjaśnieniami Angeli Merkel brak automatyzmu oznacza, że przewodniczącym KE nie musi być lider partii zwycięskiej; to raczej kandydat, który będzie w stanie zgromadzić wokół siebie większość parlamentarną ${ }^{35}$. Hipotetycznie może się zdarzyć, że wybory wygra partia eurosceptyczna, wówczas RE będzie mogła jako kandydata na szefa KE przedstawić lidera proeuropejskiej większości.

Warto wspomnieć, że - pomimo wielu kontrowersji - główne partie polityczne rozpoczęły proces selekcji wiodących kandydatów przed wyborami w 2019 r. Brak jednak pewności, czy RE uwzględni wybór elektoratu, co powoduje, że urzędujący szefowie rządów czy głowy państw nie będą zainteresowani kandydowaniem, trudno też będzie przekonać wyborców, że ich głos ma znaczenie.

32 European Parliament Decision of 7 February 2018 on the Revision of the Framework Agreement on Relations between the European Parliament and the European Commission (2017/2233(ACI)), P8_TA-PROV(2018)0030.

33 J.-C. Juncker, Orędzie o stanie Unii w 2017 r., Luksemburg 2017, s. 19.

34 D. M. Herszenhorn, M. de la Baume, EU Leaders: We Won't Be Bound by Spitzenkandidat Process, „Politico” 2018, 23 II, [online] https://www.politico.eu/article/jean-claude-juncker-spitzenkandidat-eu-leaders-we-wont-be-bound-by-spitzenkandidat-process/, 30 III 2018. 


\section{BIBLIOGRAFIA}

Arnim H.H. von, Schurig M., The European Party Financing Regulation, Münster 2004.

European Parliament Decision of 7 February 2018 on the Revision of the Framework Agreement on relations between the European Parliament and the European Commission (2017/2233(ACI)), P8_TA-PROV(2018)0030.

Final communique of the Paris Summit (9 and 10 December 1974), „Bulletin of the European Communities", nr 12, Luxembourg, XII 1974, [online] http://www.cvce.eu/obj/final_communique_of_the_paris_summit_9_and_10_december_1974-en-2acd8532-b271-49ed-bf63-bd8131180d6b. html.

Gagatek W., Mechanizm wyłaniania kandydatów na przewodniczącego Komisji Europejskiej przez partie polityczne na poziomie europejskim: geneza, założenia, konsekwencje polityczne $\mathrm{i}$ instytucjonalne (w druku).

Gorgol A., Prawne aspekty publicznego finansowania partii politycznych $w$ Polsce i na poziomie europejskim, Lublin 2011.

Hecke S. van, Do Transnational Party Federations Matter? (... and Why Should We Care?), „Journal of Contemporary European Research" 2010, vol. 6, nr 2.

Herszenhorn D.M., de la Baume M., EU Leaders: We Won't Be Bound by Spitzenkandidat process, „Politico” 2018, 23 II, [online] https://www.politico.eu/article/jean-claude-juncker-spitzenkandidat-eu-leaders-we-wont-be-bound-by-spitzenkandidat-process/.

Hix S., The Transnational Party Federations, [w:] Political Parties and the European Union, red. J. Gaffney, London-New York 1996.

Jastrzębski M., Status prawny partii politycznych na poziomie europejskim, [w:] T. Godlewski [i in.], Wspótczesne partie polityczne. Wybrane problemy, Toruń 2009.

Jednolity Akt Europejski, Dz.U. UE L 169, 29 VI 1987.

Johansson K.M., Towards a Theory of Federations of Political Parties in Multilevel Europe: at the Nexus of International Relations and Comparative Politics, [w:] The Europarties. Organisation and Influence, red. P. Delwit, E. Külahci, C. Van de Walle, Brussels 2004.

Juncker J.-C., Orędzie o stanie Unii w 2017 r., Luksemburg 2017.

Kosowska-Gąstoł B., Europejskie partie polityczne jako organizacje wielopoziomowe. Rozwój, struktury, funkcje, Kraków 2014.

Kosowska-Gąstoł B., „Partie polityczne na poziomie europejskim” - stan obecny i perspektywy rozwoju, [w:] Nowe strategie na nowy wiek. Granice i możliwości integracji regionalnych i globalnych, red. M. Chorośnicki [i in.], Kraków 2013.

Peglis M., How Can European Political Parties Maximise Their Success in the 2019 Elections?, „European View” 2-15, vol. 14, nr 1, [online] https://doi.org/10.1007/s12290-0150354-6.

Podstawy prawne Unii Europejskiej. Traktat z Lizbony, Traktat o Unii Europejskiej, Traktat o funkcjonowaniu Unii Europejskiej wraz z protokotami i deklaracjami, Karta Praw Podstawowych. Teksty skonsolidowane traktatów uwzględniające korekty językowe, wprow., wybór i oprac. J. Barcz, Warszawa 2010. 
Put G.-J. [i in.], The Choice of Spitzenkandidaten: A Comparison Analysis of the Europarties' Selection Procedures, „Politics and Governance” 2016, vol. 4, nr 1, [online] https://doi. org/10.17645/pag.v4i1.469.

Rozporzadzenie (WE) Nr 2004/2003 Parlamentu Europejskiego i Radyz dnia 4 listopada 2003 r. $w$ sprawie przepisów regulujących partie polityczne na poziomie europejskim oraz zasad dotyczacych ich finansowania, Dz.U. UE L 297, 15 XI 2003.

Rozporzadzenie (WE) nr 1524/2007 Parlamentu Europejskiego i Rady z dnia 18 grudnia 2007 r. zmieniajace rozporzadzenie (WE) nr 2004/2003 w sprawie przepisów regulujacych partie polityczne na poziomie europejskim oraz zasad dotyczacych ich finansowania, Dz.U. UE L 343, 27 XII 2007.

Rozporzadzenie (EU, Euratom) Parlamentu Europejskiego i Rady nr 1141/2014 z dnia 22 października 2014 r. w sprawie statusu i finansowania europejskich partii politycznych $i$ europejskich fundacji politycznych, Dz.U. UE L 317, 4 XI 2014.

Traktat lizbon'ski, Dz.U. UE C 306, 17 XII 2007.

Traktat o Unii Europejskiej (traktat z Maastricht), Dz.U. UE C 191, 29 VII 1992.

Traktat z Amsterdamu, Dz.U. UE C 340, 10 XI 1997.

Traktat $z$ Nicei, Dz.U. UE C 80, 10 III 2001.

Dr hab. Beata KOSOWSKA-GĄSTOŁ, adiunkt w Instytucie Nauk Politycznych i Stosunków Międzynarodowych Uniwersytetu Jagiellońskiego w Krakowie. Jej zainteresowania naukowe koncentrują się na teorii partii i transnarodowej współpracy partii w Europie. Jest autorką i współautorką publikacji z tego zakresu, m.in.: Europejskie partie polityczne jako organizacje wielopoziomowe. Rozwój, struktury, funkcje (2014); Organizational Structures of Political Parties in Central and Eastern European Countries (2016). 